\title{
Pocung Bingkas Corona dan Gambub Kurasing Hawa: Inovasi dan Media Edukasi Hidup Sehat di Era Pandemi COVID-19
}

\author{
Wiwien Widyawati Rahayu \\ Fakultas Ilmu Budaya, Universitas Gadjah Mada \\ Korespondensi: wiwien.fib@ugm.ac.id
}

\begin{abstract}
The COVID-19 pandemic is a challenge for all of us to always being enthusiastic in all activities though limited physically. The enthusiasm in all activities must also be balanced with strong motivation to maintain personal health against the pandemic. Implementation of health protocols, especially hand washing and wearing masks everywhere and everytime is becoming a key matter. Through GERMAS, the government urges all Indonesian people to implement health protocols, but over time people would feel bored with the existing socialization styles, which has also emerged in the Manggis community as the main target of Community Service (PkM). The solution offered by the FIB UGM Community Service team is an innovation in the form of application of health protocols socialization collaborating cultural elements (macapat) with the emergence of washing hands and wearing masks. Innovation is manifested in the macapat song Pocung Bingkas Corona and Gambuh Kurasing Hawa. The implementation method has done through the ToT (Training of Trainers) process, aiming the socialization with the two macapat songs ito educate and motivate the people of Manggis and the general audience to implement health protocols and understand the important elements of washing hands and using masks.
\end{abstract}

Keywords: education; health protocol; innovation; macapat pocung-gambuh; socialization of healthy life

\begin{abstract}
Abstrak
Pandemi COVID-19 menjadi tantangan bagi kita semua untuk selalu bersemangat dalam segala aktivitas meskipun dibatasi secara fisik. Semangat dalam segala aktivitas juga harus diimbangi dengan motivasi kuat dalam menjaga kesehatan diri terhadap pandemi. Pelaksanaan protokol kesehatan, khususnya mencuci tangan dan menggunakan masker di mana pun dan kapan pun, menjadi hal utama. Pemerintah melalui GERMAS (Gerakan Masyarakat Hidup Sehat) mengimbau seluruh masyarakat Indonesia untuk menerapkan protokol kesehatan, tetapi seiring berjalannya waktu, masyarakat merasa jenuh dengan gaya sosialisasi yang ada, yang juga muncul pada masyarakat Manggis sebagai sasaran utama Pengabdian kepada Masyarakat (PKM). Solusi yang ditawarkan oleh tim Pengabdian Masyarakat FIB UGM adalah inovasi bentuk sosialisasi penerapan protokol kesehatan dengan cara kolaborasi unsur budaya (macapat) dengan esensi protokol kesehatan, yakni mencuci tangan dan memakai masker. Inovasi diwujudkan dalam tembang macapat Pocung Bingkas Corona dan Gambuh Kurasing Hawa. Metode pelaksanaan $\mathrm{PkM}$ ini melalui proses ToT (Training of Trainers), yang bertujuan menggunakan kedua tembang untuk sarana sosialisasi dalam mengedukasi serta memotivasi masyarakat Manggis dan juga khalayak umum untuk melaksanakan protokol kesehatan serta memahami unsur-unsur penting dalam mencuci tangan dan menggunakan masker.
\end{abstract}

Kata kunci: edukasi; inovasi; macapat pocung-gambuh; protokol kesehatan; sosialisasi hidup sehat 


\section{Pendahuluan}

COVID-19 adalah penyakit menular yang mirip dengan keluarga virus yang menyebabkan SARS (Severe Acute Respiratory Syndrome) dan sejumlah influenza biasa. Virus tersebut muncul sekitar bulan Desember tahun 2019. Belum diketahui secara pasti mengenai asal mula dari mana datangnya virus tersebut. COVID-19 ditularkan orang yang terjangkit melalui droplet (percikan ketika seseorang berbicara), kontak berat, seperti cium tangan, jabat tangan, dan berpelukan, serta menyentuh benda yang terkontaminasi, karena virus corona dapat bertahan di permukaan benda mati selama berjam-jam hingga berhari-hari. Bahkan penelitian lebih lanjut mengungkapkan bahwa COVID-19 tersebut mampu bertahan dalam udara bebas (World Health Organization Indonesia, 2020).

Seiring berjalannya waktu, jumlah kasus penderita akibat COVID-19 tersebut semakin bertambah. Bahkan, hampir semua belahan dunia terpapar pandemi COVID19. Menurut data penelitian, Johns Hopkins University Medicine mengungkapkan bahwa jumlah negara yang sudah terpapar COVID-19 per 26 Oktober 2020 adalah sebanyak 189 negara, termasuk Indonesia, dengan jumlah kasus penderita mencapai 43.421.678. Dari 189 jumlah negara yang mengalami pandemi COVID-19, Indonesia menduduki posisi ke-23 dengan jumlah kasus penderita yang masih terus bertambah hingga saat ini. Total kasus penderita COVID-19 di Indonesia per 26 Oktober 2020 mencapai 392.934 pasien dalam grafik perkembangan COVID-19 Kementerian Kesehatan RI.

Melalui Kementerian Kesehatan RI, Pemerintah sangat mengimbau seluruh lapisan masyarakat untuk melakukan pencegahan dan meningkatkan kewaspadaan. Salah satu imbauan ini diwujudkan melalui Gerakan Masyarakat Hidup Sehat (GERMAS). Imbauan untuk hidup sehat ini banyak disuarakan di seluruh pelosok wilayah NKRI, dengan tujuan menekan angka peningkatan kasus penderita COVID-19 sehingga mengurangi dampak pada berbagai sektor yang ada. Menurut Badan Pengawasan Obat dan Makanan Republik Indonesia (BPOM RI), imbauan-imbauan dalam GERMAS bagi seluruh masyarakat, antara lain, adalah selalu mencuci tangan menggunakan sabun minimal 20 detik sebelum dan sesudah berkegiatan, selalu menggunakan masker dengan ketentuan yang sudah ditetapkan apabila bepergian ke luar rumah, physical distancing atau saling menjaga jarak, dan protokol kesehatan lainnya. Rajin mencuci tangan dan mengenakan masker ketika beraktivitas di luar rumah menjadi poin utama yang ditekankan dalam GERMAS. Kedua pola hidup sehat tersebut merupakan salah satu langkah preventif dari individu masing-masing untuk mencegah diri dari terpapar COVID-19.

Sosialisasi mengenai gerakan hidup sehat pada masyarakat selalu diberikan dengan tujuan mengingatkan dan mengimbau masyarakat untuk selalu menerapkannya dengan kesadaran tinggi, tetapi sejauh observasi yang dilakukan terhadap bentuk dan media, sosialisasi penerapan gaya hidup sehat-khususnya mencuci tangan dan mengenakan masker-hanya dalam bentuk poster, video, dan sosialisasi secara lisan saja sehingga masyarakat mudah merasa bosan dengan banyaknya sosialisasi tersebut (protokol kesehatan pada era pandemi COVID-19). Kejenuhan terhadap cara sosialisasi sangat tinggi dalam masyarakat pedesaan. Mereka merasa dengan banyaknya sosialisasi, baik lisan dalam pertemuan warga maupun tulisan dalam pamflet atau poster di berbagai tempat, membuat mereka merasa terbebani dan bosan. Tujuan dari sosialisasi tersebut 
kurang dapat diterima, khususnya bagi masyarakat desa. Oleh karena itu, diperlukan adanya inovasi terhadap bentuk sosialisasi penerapan protokol kesehatan dengan kolaborasi unsur potensi lokal daerah dengan esensi dari protokol kesehatan yang ada.

Pandemi COVID-19 secara tidak langsung membuat aktivitas manusia terbatasi dalam hal pertemuan yang menghendaki adanya kontak fisik. Berbagai lini kehidupan, baik ekonomi, sosial, politik, kesehatan, maupun budaya, mengalami dampak yang sangat signifikan. Pada bidang budaya, misalnya, proses edukasi budaya dalam masyarakat terhambat karena adanya pandemi. Dulu sebelum ada pandemi, banyak sekali pagelaran budaya sebagai media sosialisasi dan edukasi dilakukan, tetapi untuk sementara waktu, kegiatan ini ditangguhkan. Kondisi seperti ini menjadi ladang pemikiran kritis dalam menyiapkan solusi dari adanya dampak pandemi tersebut. Oleh karena itu, inovasi penerapan pola hidup sehat dalam protokol kesehatan COVID-19 berbasiskan budaya diharapkan mampu memberikan semangat bangkit dalam berbudaya dan tentunya menjaga kesehatan diri.

Inovasi yang sangat mungkin dilakukan adalah mengolaborasikan antara unsur budaya daerah sebagai potensi lokal daerah dengan protokol kesehatan yang hendak disampaikan. Budaya daerah-khususnya seni tradisi lisan, yaitu macapat-merupakan media paring pitutur atau pemberian petuah-petuah bijak serta penuangan nasihat yang sudah digunakan oleh nenek moyang Jawa, khususnya dalam mendidik, menasihati, dan memberikan ilmu dalam setiap syair-syair di dalamnya (Koentjaraningrat, 1984:2015216). Tembang macapat merupakan salah satu warisan budaya Jawa yang cukup terkenal. Macapat merupakan sebutan puisi tradisional dalam bahasa Jawa yang disusun dengan metrum atau aturan tembang tertentu, yang terkait dengan jumlah baris, jumlah suku kata, ataupun bunyi vokal pada sajak terakhir setiap baris (guru gatra, guru wilangan, dan guru lagu) (Darusuprapta, 1989:7-10). Tembang macapat digolongkan sebagai tembang cilik yang bentuk setiap macapatnya tidak sepanjang syair lagu-lagu saat ini. Oleh karena itu, macapat sebagai media inovasi dan edukasi dalam pemahaman akan pentingnya hidup sehat sangatlah relevan, terlebih lagi dalam memenuhi 20 detik waktu minimal mencuci tangan yang sesuai dengan waktu penembangan tembang Pocung. Terdapat 11 jenis tembang macapat yang dikenal luas oleh masyarakat Jawa dengan watak tembang yang berbeda pula (Haidar, 2018).

Selanjutnya, tembang macapat menurut Poerwadarminta (1939) dalam Baoesatra Jawa adalah "Iketan karangan awewaton guru lagu sarta guru wilangan apadene kanthi lelagon". Ikatan karangan atau puisi ialah suatu bentuk karya sastra yang terikat oleh aturan irama, matra, dan rima dalam setiap susunan lariknya. Tembang macapat bersinonim dengan puisi berbahasa Jawa atau geguritan tradisional. Sebutan lain dari macapat adalah tembang cilik atau tembang lumrah (Gericke dan Roorda, 1901:708). Karena berikatan dengan sebuah rima dan irama, dalam praktiknya, tembang macapat disajikan dengan menggunakan sebuah lagu atau cengkok.

Inovasi sosialisasi penerapan gaya hidup sehat kepada masyarakat-khususnya masyarakat pedesaan-diharapkan mampu menarik kemauan, mengedukasi, serta memotivasi semua lapisan masyarakat untuk selalu mencuci tangan dan mengenakan masker di mana pun dan kapan pun. Contoh edukasi dan inspirasi kepada masyarakat mengenai tata cara menjaga kebersihan dan pola hidup sehat pada masa pandemi COVID-19 dan setiap harinya sebagai kebiasaan, dipilihlah tembang macapat Pocung 
dan Gambuh yang masing-masingnya memiliki watak yang berbeda dan disesuaikan dengan pesan atau esensi makna yang akan disampaikan. Secara umum, kedua tembang tersebut memiliki watak ceria, selaras, ringan, dan luwes atau tidak terkesan kaku sehingga dapat menghibur serta menjadi media edukasi bagi seluruh lapisan masyarakat, khususnya masyarakat budaya yang ada di pedesaan.

Dipilihnya tembang macapat sebagai sebuah inovasi bentuk sosialisasi penyampaian dan pemahaman gaya hidup sehat kepada masyarakat bertujuan supaya masyarakat tidak merasa jenuh dengan gaya atau bentuk sosialisasi yang sudah ada. Sekaligus secara tidak langsung dapat mengenalkan kembali, menumbuhkan minat, mengembangkan potensi, dan akhirnya menguatkan eksistensi tembang macapat bagi seluruh lapisan masyarakat, baik anak muda hingga dewasa. Era pandemi diharapkan tidak menjadi sebuah hambatan dalam berproses dan belajar, dengan catatan bahwa penerapan protokol kesehatan harus selalu dilakukan. Melalui kolaborasi budaya macapat dengan protokol kesehatan yang dianjurkan oleh KEMENKES RI sebagai bentuk inovasi sosialisasi penerapan gaya hidup sehat, khususnya mencuci tangan dan memakai masker, seluruh lapisan masyarakat dapat belajar dan memahami pentingnya menjaga kesehatan diri pada era pandemi dengan tetap berbudaya.

Pihak yang disasar dalam kegiatan ini adalah seluruh masyarakat terdampak pandemi COVID-19 pada umumnya, khususnya masyarakat Desa Manggis, Kecamatan Panggul, Kabupaten Trenggalek, Jawa Timur, baik anak-anak maupun orang dewasa. Hal ini didasarkan pada imbauan pemerintah yang sangat menganjurkan seluruh lapisan masyarakat untuk selalu menerapkan gaya hidup sehat sesuai protokol kesehatan, khususnya pada level individu. Masyarakat Manggis dipilih karena merupakan salah satu masyarakat dengan lokalitas daerah atau seni budaya yang masih tinggi, yaitu dengan adanya seni tayub, jaranan, dan macapatan (Salam, 2019:35-38).

Masyarakat budaya di Desa Manggis merasa jenuh dengan adanya sosialisasisosialisasi protokol kesehatan yang ada. Sebagai salah satu desa wisata budaya, masyarakat Manggis sangat relevan sebagai target sasaran dalam PkM COVID-19 mengenai inovasi bentuk sosialisasi protokol kesehatan berbasiskan budaya Jawa melalui tembang macapat.

\section{Tujuan Kegiatan}

Berdasarkan masalah yang diuraikan sebelumnya, pengabdian kepada masyarakat (PkM) ini bertujuan sebagai berikut.

- Menyusun produk inovasi bentuk sosialisasi penerapan pola hidup sehat pada era pandemi berbasiskan kolaborasi budaya berupa tembang macapat dengan esensi protokol kesehatan sebagai tawaran solusi atas kejenuhan masyarakat.

- Memberikan pelatihan dan pendampingan secara tidak langsung (nonfisik) sehingga mampu mengukur ketercapaian kegiatan PkM.

\section{Metode Pelaksanaan}

Metode inovasi bentuk sosialisasi yang dilakukan dalam pelaksanaan Pengabdian kepada Masyarakat (PkM) Tembang Pocung dan Gambuh sebagai Media Edukasi Gaya Hidup Sehat pada Masyarakat Berbasis Budaya Jawa ialah pengedukasian masyarakat sasaran 
dengan cara pelatihan tidak langsung (ToT (Training of Trainers)) dan pendampingan melalui pemanfaatan media virtual yang sudah tersedia secara daring. Pembahasan dan materi yang menjadi tujuan utama mengenai pemahaman dan edukasi pentingnya gaya hidup sehat disampaikan dalam bentuk video. Video tersebut diunggah dalam platform media audiovirtual, yaitu YouTube. YouTube dipilih karena dianggap sebagai salah satu media audiovirtual yang sering diakses oleh masyarakat, khususnya masyarakat (terpilih yang akan menjadi penghubung) di Desa Manggis sehingga tujuan dari kegiatan ini dapat tercapai secara maksimal. Melalui video yang diunggah ke YouTube, diharapkan masyarakat sasaran teredukasi dan terinspirasi dengan cara menonton, memahami, mempraktikkan, dan menularkan atau mengajarkan pesan serta anjuran hidup sehat yang termuat dalam video tersebut secara terus-menerus.

Pesan atau isi dari video edukasi pentingnya gaya hidup sehat-mencuci dan menggunakan masker - tersebut didesain dengan gaya visualisasi prosedur atau tata cara mencuci tangan dan pemilihan masker serta penggunaannya yang benar, diiringi dengan nyanyian tembang macapat Pocung Bingkas Corona dan Gambuh Kurasing Hawa yang berisikan prosedur-prosedur protokol kesehatan COVID-19. Dengan demikian, masyarakat sasaran diharapkan mampu menirukan dan memahami penjelasan yang diberikan seperti diberi arahan secara langsung dengan ajakan melalui kegiatan nembang atau menyanyikan tembang sehingga seluruh syarat penerapan protokol kesehatan, misalnya mencuci tangan menggunakan sabun dengan air bersih yang mengalir dengan durasi minimal 20 detik dan menggunakan masker serta pemilihannya dapat teraplikasikan secara baik dan sesuai dengan protokol kesehatan.

Bentuk pelaksanaan kegiatan PkM (Pengabdian kepada Masyarakat) dilaksanakan secara berjenjang. Kegiatan ini melibatkan sebanyak kurang lebih tiga sampai dengan lima masyarakat sasaran yang terpilih sebagai perwakilan/tutor desa dengan model ToT (Training of Trainers). Model ToT disampaikan secara daring, yaitu dengan menonton video tutorial. Hal ini diharapkan mampu menjadi motivasi tutor dalam menyampaikan/ mengajarkan kepada masyarakat di sekitarnya dengan cara menembangkan tembang yang telah disiapkan. Pelatihan menembang dilakukan secara daring atau dalam jaringan dengan praktik serta uji coba sampai masyarakat tutor tersebut mampu menembangkan dengan baik materi tembang yang telah disiapkan. Selain itu, leaflet juga dibagikan kepada masyarakat sasaran agar masyarakat tersebut dapat lebih mudah memahami dan mengingat jika materi diwujudkan dalam bentuk tulisan.

Selain produk inovasi bentuk sosialisasi penerapan protokol kesehatan berbasiskan budaya, yakni berupa Tembang Pocung Bingkas Corona dan Gambuh Kurasing Hawa yang ditujukan kepada masyarakat budaya di Desa Manggis, produk tersebut juga diperluas masyarakat sasarannya, yaitu kepada seluruh masyarakat terdampak pandemi COVID19 di Indonesia. Secara tidak langsung, produk edukasi yang diunggah ke YouTube juga mendapatkan respons dari berbagai netizen (warganet) YouTube dan berbagai media sosial lainnya. Respons tersebut akan dijelaskan dalam pembahasan selanjutnya.

Setelah pelatihan secara tidak langsung dilakukan, selanjutnya dilanjutkan dengan pendampingan dan pemantauan keberterimaan serta respons masyarakat sasaran terhadap produk PkM berupa Tembang Pocung Bingkas Corona dan Gambuh Kurasing Hawa tersebut. Pengukuran respons masyarakat sasaran dilakukan dengan menggunakan kuesioner yang diperluas penyebarannya karena sesuai dengan tujuan dari $\mathrm{PkM}$ ini, 


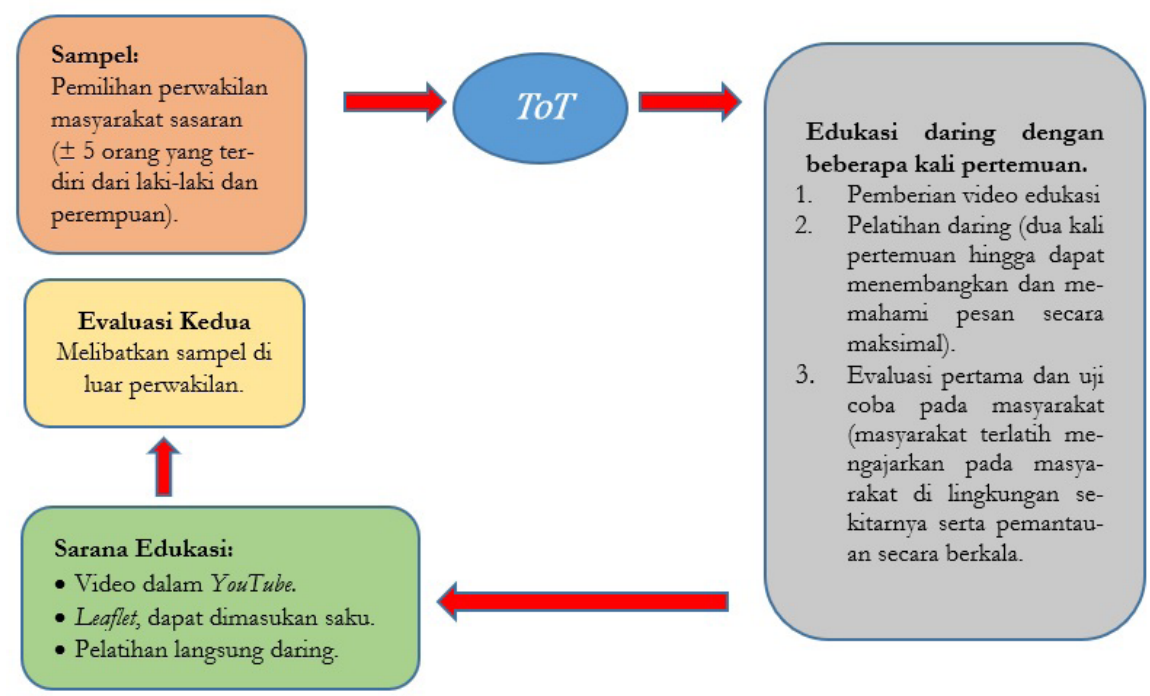

Gambar 1. Pelaksanaan Program Pengabdian kepada Masyarakat

yakni memberikan tawaran inovasi bentuk penerapan pola hidup sehat sesuai dengan protokol kesehatan yang tidak membosankan dan tentu saja dengan tetap memenuhi syarat utama dalam mencuci tangan dan mengenakan masker.

\section{Tembang Macapat sebagai Solusi Atasi Kejenuhan}

Kejenuhan yang muncul pada masyarakat budaya di Desa Manggis dilatarbelakangi oleh sifat sosialisasi penerapan protokol kesehatan yang monoton, yang dilakukan melalui media visual seperti pamflet, baliho, banner, serta secara lisan berupa orasi maupun imbauan langsung melalui berbagai pertemuan, seperti pertemuan PKK dan pertemuan desa lainnya. Sebagai masyarakat budaya, mereka merasakan adanya rasa seni yang tidak tersalurkan dan kurang luwesnya sosialisasi protokol kesehatan yang ada. Rasa jenuh yang terus-menerus dibiarkan dapat membuat masyarakat semakin tak acuh dan menganggap COVID-19 sebagai penyakit biasa. Di sinilah diperlukan perhatian khusus guna menghilangkan rasa jenuh tersebut dan justru menciptakan semangat untuk selalu menerapkan protokol kesehatan di setiap kegiatan masyarakat, khususnya pada level individu.

Lagu yang terkandung pada setiap tembang macapat, khususnya pocung dan gambuh, menjadi poin penting dalam penyampaian dan pemahaman protokol kesehatan COVID-19 tersebut. Tembang macapat pocung dan gambuh yang digunakan sebagai media utama dalam menyampaikan pesan mengenai pentingnya penerapan protokol kesehatan pada era pandemi COVID-19 dipilih berdasarkan penyesuaian antara watak tembang, karakter, bentuk, dan lagu setiap tembang dengan pesan atau isi yang hendak disampaikan. Dari 11 jenis tembang macapat, tembang pocung dan gambuh merupakan tembang yang sudah sangat familier bagi mayoritas orang Jawa. Keberadaan kedua jenis tembang tersebut erat kaitannya dengan permainan tradisional anak yang berisikan tebak-tebakan dan pesan-pesan budi pekerti (Nugrahani, 2012:12).

Tembang macapat Pocung Bingkas Corona dan Gambuh Kurasing Hawa dihadirkan 
untuk mengatasi kejenuhan dan menyalurkan jiwa seni, khususnya bagi masyarakat Manggis. Kedua tembang tersebut dipilih karena memiliki watak yang ceria dan ramah. Selain itu, secara khusus, tembang pocung memiliki watak santai, jenaka, seenaknya, dan sedih (Sudaryanto, 1989:13) ${ }^{1}$. Karena watak yang terkandung dalam pocung adalah santai, jenaka, ceria, dan ramah, tembang ini dipilih untuk menyampaikan pemahaman atas pentingnya mencuci tangan yang didesain dengan menggunakan bahasa yang mudah dipahami, khususnya bagi anak-anak atau kaum muda. Tembang pocung sangatlah cocok digunakan sebagai media tutorial atau prosedur karena bentuk tembangnya yang singkat dengan lagu yang mudah untuk ditembangkan atau dinyanyikan. Sementara itu, tembang gambuh memiliki watak jelas, wajar, tanpa ragu-ragu, apa adanya, lugas, dan polos (Sudaryanto, 1989:13). Sifat tembang gambuh tersebut sangat relevan untuk menjelaskan pentingnya menggunakan masker dengan syarat-syarat utamanya.

KEMENKES RI menghimbau agar selain menerapkan protokol kesehatan dalam kehidupan sehari-hari, masyarakat juga harus memahami adanya syarat-syarat utama sebagai kunci dari pola hidup sehat tersebut. KEMENKES RI ${ }^{2}$ menyatakan bahwa syarat utama dalam mencuci tangan dan memakai masker antara lain adalah (1) Mencuci tangan menggunakan air bersih yang mengalir, menggunakan sabun, minimal selama 20 detik, dibersihkan dengan menggunakan air mengalir, dikeringkan dengan lap atau tisu yang bersih; dan (2) Memakai masker ketika beraktivitas di luar, masker harus menutupi seluruh bagian mulut dan hidung, bersih, maksimal penggunaan 4 jam, mengganti masker dan mencucinya dengan sabun (Direktorat Jenderal Pencegahan dan Pengendalian Penyakit, 2020).

Syarat-syarat pokok ketika mencuci tangan dan mengenakan masker diadaptasi dan ditransformasikan bentuknya menjadi sebuah tembang macapat, yaitu Pocung Bingkas Corona dan Gambuh Kurasing Hawa.

\section{Pocung Bingkas Corona-Tawaran Inovasi Cuci Tangan}

Masing-masing tembang tersaji dalam dua bait. Tembang Pocung Bingkas Corona bait pertama berisikan edukasi dan pemahaman terhadap syarat utama yang harus dipenuhi dalam mencuci tangan sesuai dengan anjuran Kementerian Kesehatan RI. Judul Pocung Bingkas Corona didasarkan pada harapan dalam terciptanya tembang ini, yaitu dengan bersaranakan macapat pocung, virus corona dapat dibingkas atau dimusnahkan. Esensi pentingnya adalah jika kita bisa memahami isi dari tembang pocung ini dan mempraktikkannya ketika kita mencuci tangan sebagai langkah preventif dalam menghindari COVID-19. Kata pocung dapat berkorelasi dengan kata pocong, yang bagi masyarakat Jawa pocong atau pocongan adalah kondisi ketika seseorang telah mati (Rossandy, 2016:191) .

Tembang Pocung Bingkas Corona di atas dikemas menggunakan bahasa Jawa ragam ngoko dengan maksud agar tujuan isi atau pesan yang terkandung di dalam tembang dapat dipahami secara mudah oleh masyarakat sasaran, yaitu anak-anak dan orang dewasa.

1 Tersaji dalam Laporan Penelitian Tim Balai Penelitian Bahasa Yogyakarta, "Macapat dalam Bahasa Jawa”, 1989, Koleksi perpustakaan Fakultas Ilmu Budaya UGM.

2 Dalam Pedoman Pencegahan dan Pengendalian (P2P) Coronavirus Disease (COVID-19), Direktorat Jenderal Pencegahan dan Pengendalian Penyakit, Maret 2020.

3 Konteks mati inilah yang dimasukkan sebagai bagian dari harapan supaya pandemi COVID-19 
Tabel 1. Guru Gatra, Guru Wilangan, Guru Lagu, dan Arti

\begin{tabular}{|c|l|l|}
\hline \multicolumn{2}{|c|}{ TEMBANG POCUNG BINGKAS CORONA BAIT 1 } \\
\hline \multicolumn{2}{|c|}{ (Mencuci Tangan Menggunakan Sabun dan Air Bersih Mengalir Minimal 20 Detik) } \\
\hline $12 \mathrm{U}$ & Panyegahing corona sarana wisuh & $\begin{array}{l}\text { Pencegahan corona dengan } \\
\text { cara mencuci (tangan) }\end{array}$ \\
\hline $6 \mathrm{~A}$ & Tangan loro sira & Kedua tanganmu \\
\hline $8 \mathrm{I}$ & Sabunen rong puluh dhetik & Sabunlah (minimal) dua puluh detik \\
\hline $12 \mathrm{~A}$ & Banyu mili resikana nganti rata & $\begin{array}{l}\text { (Menggunakan) air mengalir, bersihkanlah } \\
\text { dengan merata keseluruhan. }\end{array}$ \\
\hline
\end{tabular}

* Cakepan (syair) diganti dari yang sebelumnya: "Kabèh rata aja nganti ora kena". Penggantian syair pada gatra atau baris keempat tembang Pocung Bingkas Corona ini didasarkan pada urgensinya pemasukan frasa "banyu mili" dalam tembang tersebut. Meskipun syair pada baris keempat diganti, hal ini tidak menghilangkan substansi pada syair sebelumnya, yaitu tangan harus dicuci secara merata atau keseluruhan. Kata "rata" juga dihadirkan kembali pada cakepan atau syair yang baru.

Tabel 2. Guru Gatra, Guru Wilangan, Guru Lagu, dan Arti

\begin{tabular}{|c|c|c|}
\hline \multicolumn{3}{|c|}{ TEMBANG POCUNG BINGKAS CORONA 2} \\
\hline \multicolumn{3}{|c|}{ (Prosedur Mencuci Tangan Minimal 20 Detik) } \\
\hline $12 U$ & Telesana èpèk-èpèk karo sabun* & Basahilah telapak tangan(mu) dengan sabun \\
\hline $6 \mathrm{~A}$ & Ngisor ndhuwur rata** & Atas bawah harus merata \\
\hline 81 & Sela-sela kuku driji & (Hingga) sela-sela kuku (dan) jari \\
\hline $12 \mathrm{~A}$ & $\begin{array}{l}\text { Maju mundur munyer } \\
\text { nyilang gosokana }\end{array}$ & Maju mundur memutar menyilang gosoklah \\
\hline
\end{tabular}

* Menyederhanakan tahapan: membasahi tangan dengan menggunakan air dan mengambil sabun secukupnya.

** Menjelaskan bahwa dengan kondisi permukaan tangan bagian atas dan bawah harus rata, semua bagian basah terkena air dan sabun.

*** Prosedur sesuai Kemenkes: menggosok kedua telapak tangan dan punggung tangan, sela-sela kuku dengan jari tangan, menggosok jari jemari dengan rapat-rapat, serta menggosok bagian ibu jari kiri dan kanan.

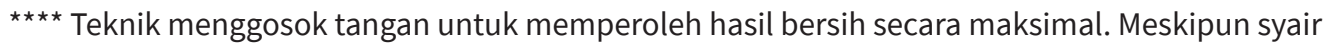
lagu tersebut adalah syair terakhir, tidak lupa pembilasan dilakukan dan kedua tangan dikeringkan dengan menggunakan lap yang bersih.

Hal yang ditekankan adalah substansi utama dalam mencuci tangan, yaitu kebersihan kedua telapak tangan dari kuman dan virus. Sesuai dengan protokol kesehatan, halhal yang harus dilakukan dalam mencuci tangan adalah menggunakan air mengalir, sabun, dengan durasi minimal 20 detik, serta lakukan secara merata pada seluruh bagian tangan. Syarat utama dalam mencuci tangan disimbolkan dengan penggunaan katakata berikut: sabunen rong puluh dhetik yang berarti 'sabunlah kedua tangan minimal selama 20 detik'; banyu mili resikana nganti rata yang berarti 'menggunakan air mengalir, bersihkanlah sampai merata keseluruhan'. Apabila ditarik kesimpulan, kata kunci dari bait pertama tembang ini adalah panyegahing corona, wisuh, tangan, sabun, banyu mili, 20 dhetik, rata.

segera berlalu atau sirna dari bumi pertiwi ini. 
Tembang pocung yang kedua berisikan prosedur atau langkah-langkah mencuci tangan dengan menembangkan bait kedua ini. Prosedur mencuci tangan yang baik dan benar menurut Kementerian Kesehatan terdiri atas 12 langkah. Dua belas langkah tersebut merupakan perincian hingga pendetailan, tetapi karena dalam tembang pocung dibatasi oleh adanya metrum atau aturan bahwa pocung hanya terdiri atas 4 baris, 12 langkah tersebut disarikan sehingga diperoleh 4 langkah mencuci tangan. Meskipun hanya terdiri atas 4 langkah, esensi dari 12 langkah sesuai anjuran KEMENKES masih dapat dipenuhi. Tembang ini dinyanyikan ketika seseorang mencuci tangan. Durasi penembangan dengan mencuci tangan disesuaikan dengan waktu minimal mencuci tangan, yaitu 20 detik.

\section{Gambub Kurasing Hawa-Memahami Masker}

Tembang Gambuh Kurasing Hawa merupakan tembang yang dibuat untuk mengedukasi masyarakat sasaran dan masyarakat secara luas dalam hal pentingnya mengenakan masker ketika beraktivitas di luar. Hampir setiap orang sudah memahami prosedur menggunakan masker yang benar, tetapi pemahaman mengenai syarat penggunan masker yang efektif belum banyak diketahui oleh masyarakat, khususnya masyarakat di pedesaan. Kerap sekali mereka menggunakan masker dengan anggapan "yang penting menutupi mulut", sedangkan bagian hidung masih terbuka. Melalui Gambuh Kurasing Hawa dimasukkan pemahaman mengenai syarat penggunaan masker yang baik dan benar sesuai dengan protokol kesehatan yang ada.

Nama Gambuh Kurasing Hawa digunakan sebagai judul tembang karena tujuan dari penggunaan masker adalah untuk menguras atau membersihkan hawa 'udara', sedangkan kata gambuh berarti 'paham' atau 'tahu'. Jadi, dalam judul tembang telah diselipkan secara implisit tujuan mengenakan masker secara baik dan benar. Lirik dari tembang tersebut adalah sebagai berikut.

Tabel 3. Guru gatra, guru wilangan, guru lagu, dan arti

\begin{tabular}{|c|l|l|}
\hline \multicolumn{2}{|c|}{ TEMBANG GAMBUH KURASING HAWA } \\
\hline \multicolumn{2}{|c|}{ (Pentingnya Masker Kain dan Penggunaannya) } \\
\hline $7 \mathrm{U}$ & Aja lali maskermu & Jangan lupa (gunakan/pakai) maskermu \\
\hline $10 \mathrm{U}$ & Masker kain nggonen yèn rep metu & $\begin{array}{l}\text { Masker kain pakailah Ketika } \\
\text { hendak keluar (bepergian) }\end{array}$ \\
\hline $12 \mathrm{U}$ & Kang saraté tangan resik masker resik & $\begin{array}{l}\text { Syaratnya, tangan bersih (dan) } \\
\text { masker harus bersih }\end{array}$ \\
\hline 80 & Patang jam maksimal wektu & $\begin{array}{l}\text { Empat jam maksimal } \\
\text { penggunaan masker }\end{array}$ \\
\hline
\end{tabular}

Pemahaman yang ditekankan dalam syair tembang Gambuh Kurasing Hawa adalah penggunaan masker kain dengan kondisi yang selalu bersih serta penggunaannya harus menutupi seluruh bagian mulut dan hidung dengan nyaman (tidak membuat sesak napas). Waktu maksimal penggunaan masker adalah 4 jam, setelah itu masker hendaknya dicuci menggunakan sabun hingga bersih. 
Tabel 4. Guru gatra, guru wilangan, guru lagu, dan arti

\begin{tabular}{|c|l|l|}
\hline \multicolumn{2}{|c|}{ TEMBANG GAMBUH KURASING HAWA } \\
\hline \multicolumn{2}{|c|}{ (Prosedur Penggunaan) } \\
\hline $7 \mathrm{U}$ & Prosedhuré yaiku & Prosedurnya yaitu \\
\hline $10 \mathrm{U}$ & Kang dèn kayuh talining satuhu & $\begin{array}{l}\text { Yang dipegang (adalah) } \\
\text { talinya (tali maskernya) }\end{array}$ \\
\hline $12 \mathrm{I}$ & Kudu gugu masker rapet lan nutupi & $\begin{array}{l}\text { Harus nurut (bahwa) masker } \\
\text { (harus) rapat dan menutupi }\end{array}$ \\
\hline $8 \mathrm{U}$ & Tangan anteng nora dumuk & Tangan diam tidak memegang (masker) \\
\hline 80 & Kudu kumbah bubar dinggo & Selesai digunakan harus dicuci \\
\hline
\end{tabular}

Bait kedua dari tembang Gambuh Kurasing Hawa adalah menjelaskan prosedur penggunaan masker serta kondisi diri kita ketika telah menggunakan masker. Bahasa yang digunakan tidak lagi menggunakan bahasa Jawa ngoko secara keseluruhan, tetapi ada beberapa menggunakan krama. Tujuan dari penggunaan ngoko alus dalam tembang ini adalah pesan-pesan di dalamnya mampu dirasakan nuansa kehalusannya sehingga ada korelasi antara laras $^{4}$ atau lagu yang digunakan ketika menembangkan tembang ini dengan ragam bahasa yang ditembangkan.

\section{Edukasi dan Internalisasi Nilai}

Produk inovasi bentuk sosialisasi penerapan protokol kesehatan berupa tembang macapat Pocung Bingkas Corona dan Gambuh Kurasing Hawa dalam praktik pelaksanaan kepada masyarakat menghasilkan banyak respons, khususnya penggunaan kedua tembang ini sebagai media edukasi bagi masyarakat, baik dalam lingkungan pembelajaran formal maupun nonformal. Tembang macapat sebagai media edukasi sesungguhnya telah menjadi karakteristik dari setiap metrum macapat (Wiratama dkk., 2014:78). Tembang macapat merupakan media belajar yang dahulu digunakan masyarakat Jawa di berbagai bidang kehidupan, khususnya yang terkait dengan adab sopan santun dan tata krama. Setiap metrum macapat memiliki nilai-nilai etis dan rasa edukatif yang berbeda-beda sehingga dalam penggunaannya sebagai media penanaman nilai-nilai budi pekerti kepada anak disesuaikan dengan nilai yang akan dikenalkan dan disampaikan (Chodjim, 2013).

Praktik mencuci tangan dan mengenakan masker dengan menembangkan kedua tembang pocung dan gambuh secara tidak langsung memengaruhi kognitif pembaca, pendengar, ataupun orang yang mempraktikkannya. Menurut Mahapatra dalam Cognitive Training and Reading Remediation dijelaskan bahwa membaca dengan memahami isi sebuah teks atau bacaan, mengkritisi, serta mengungkap nilai-nilai di dalam bacaan tersebut mampu meningkatkan kognitif atau kecerdasan pikiran yang tinggi (Mahapatra, 2015).

Ketika masyarakat mampu menembangkan, hal itu menunjukkan bahwa mereka telah mampu memahami isi dan manfaat yang memberikan rasa senang dalam hatinya. Ketika mereka mampu memahaminya, pesan-pesan yang disampaikan melalui tembang

4 Laras adalah jenis nada dalam gamelan (pelog atau slendro). Tembang Gambuh Kurasing Hawa tersebut menggunakan laras pelog. Laras ini memiliki karakteristik agung, berwibawa, dan lembut (Osada, 2019:4-5). 
akan melekat dalam pikiran/kognitif mereka dan akan selalu ingat ketika mereka mengetahui irama atau lagu dari tembang pocung dan gambuh ini. Karena masyarakat sasaran utama dalam PkM ini adalah anak-anak muda dan orang dewasa, pemilihan lagu dalam masing-masing tembang diharapkan dapat diterima oleh semua umur. Irama lagu tembang Pocung Bingkas Corona dan Gambuh Kurasing Hawa yang digunakan adalah lagu pocung seperti yang biasa diajarkan di Sekolah Dasar, yaitu pocung laras slendro dan gambuh laras pl. $6^{5}$.

Tembang pocung dan gambuh sebagai media edukasi bagi masyarakat di Desa Manggis juga menjadi media edukasi bagi masyarakat umum atau sasaran luas, khususnya bagi mahasiswa Sastra Jawa FIB UGM angkatan 2019 sebagai bahan kajian analisis sastra dalam mata kuliah Pengantar Ilmu

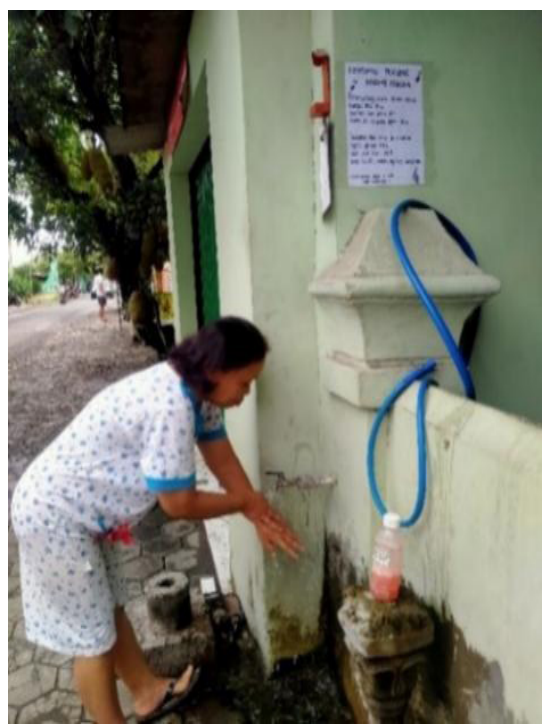

Gambar 2. Tembang Pocung Bingkas Corona sebagai edukasi warga Jetis, Tamantirto, Kasihan, Bantul. Sastra. Bagi mereka, kedua tembang yang dikemas dalam bentuk video tersebut mampu dianalisis menggunakan teori sastra, yaitu tembang Pocung Bingkas Corona dan Gambuh Kurasing Hawa menjadi sebuah produk sastra yang estetis, bermanfaat, dan praktis.

Tembang pocung dan gambuh di masyarakat di desa lain seperti Desa Jetis, Tamantirto, Kasihan, Bantul, DIY. Warga masyarakat menggunakan tembang Pocung Bingkas Corona sebagai media edukasi bagi masyarakat sekitar ketika bertamu untuk selalu mencuci tangan dengan menembangkan tembang pocung tersebut.

Meskipun tamu yang datang tidak langsung bisa, dengan membaca lirik tembang yang dipasang di dekat tempat mencuci tangan, mereka akan mencoba memahami isi tembang tersebut karena pikiran manusia merupakan alat pengatur gerak tubuh yang sangat ditentukan oleh adanya respons indra terhadap bahasa yang direkamnya (Schlenker, 2004 dalam Widhiarso, 2005:1-3). Ketika tamu tersebut membaca syair tembang yang ditempel di dekat tempat mencuci tangan (keran), secara tidak sadar ia akan mencoba mengikuti prosedur tersebut. Terlebih bahasa dalam tembang pocung merupakan bahasa ngoko yang hampir semua orang mengetahuinya. Hal ini dapat diamati pada seluruh syair lagu pocung bait kedua yang berisi mengenai prosedur mencuci tangan, misalnya "maju mundur munyer nyilang gosokana" yang berarti 'maju mundur, memutar, menyilang, gosoklah'. Mereka akan mengikuti proses-proses tersebut sebagai bagian dalam pikiran atas respons indra penglihatan mereka. Begitu pun ketika masyarakat sasaran mendengarkan video produk PkM, kognitif pikiran mereka akan terkontrol dari pengalaman mendengarkan video kedua tembang tersebut.

Internalisasi nilai-nilai yang ditanamkan dari kedua tembang (pocung dan gambuh) ialah sebagai berikut. Pertama, nilai kedisiplinan karena menembangkan dan mempraktikkan membutuhkan ketekunan dan kemauan, semuanya dapat dicapai apabila seseorang disiplin dalam melaksanakannya. Kedua, nilai budaya, masyarakat sasaran dari produk PkM mendapatkan nilai estetika budaya, antara lain penghalusan

5 Pl.6 -> laras pelog pathet nem, yaitu jenis nuansa lagu dalam sajian karawitan Jawa. 
rasa, keluwesan, dan kesantunan gerak yang diperoleh dari bahasa yang digunakan dan diresapi dalam setiap praktiknya. Ketiga, nilai edukatif melalui kajian dan edukasi masyarakat. Keempat, nilai praktis, yaitu protokol kesehatan dapat terpenuhi dengan baik dan benar sesuai dengan anjuran KEMENKES RI.

\section{Refleksi Capaian Program}

\section{Tanggapan terhadap Produk PkM}

Kegiatan pelaksanaan pengabdian ini bertujuan untuk mengatasi kejenuhan dan mengedukasi masyarakat terhadap pentingnya penerapan protokol kesehatan atau hidup sehat pada era pandemi COVID-19. Sebagai luaran dari kegiatan PkM, dihasilkan tiga produk edukasi berupa video tutorial, poster, dan leaflet yang semuanya berisikan tembang Pocung Bingkas Corona dan Gambuh Kurasing Hawa sebagai sebuah inovasi bentuk sosialisasi terhadap penerapan pola hidup sehat mencuci tangan dan mengenakan masker. Produk edukasi ini mulai disebar kepada masyarakat, baik masyarakat sasaran utama di Desa Manggis, Panggul, Trenggalek, Jawa Timur sebagai bagian masyarakat budaya yang merasakan kejenuhan maupun masyarakat umum secara nasional mulai Agustus hingga Oktober 2020. Dalam periode tiga bulan, produk ini diukur menggunakan beberapa indikator yang diharapkan ideal dengan metode kuesioner bagi masyarakat umum, termasuk juga masyarakat sasaran utama di dalamnya.

Dari 85 responden yang mengisi kuesioner secara online, diketahui persebaran data dalam rentang usia yang mengakses produk PkM berupa tembang Pocung Bingkas Corona dan Gambuh Kurasing Hawa, baik melalui video di YouTube, pembaharuan status di media sosial masing-masing, dan secara langsung melalui ToT. Diagram di atas menunjukkan bahwa rentang usia 17-30 tahun merupakan pengakses informasi terbanyak, yaitu 40\%, disusul rentang usia 10-16 tahun sebanyak 35\%, dan rentang

\section{Tanggapan Masyarakat Terhadap Produk PkM (Menurut Rentang Usia)}

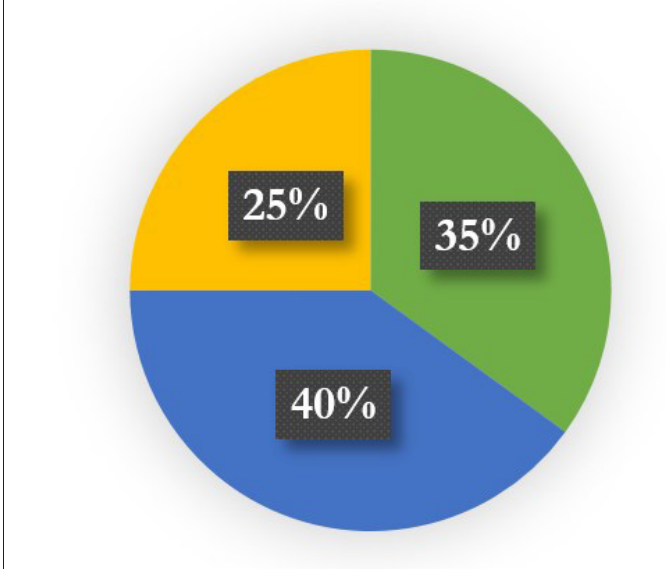

Usia 10 sampai 16 tahun

- Usia 17 sampai 30 tahun

Usia 30 sampai $>50$ tahun

Ket:

* Jumlah responden 85 orang $(55$ perempuan dan 30 laki-laki).

* Kuesioner ini diukur dalam skala nasional.

Diagram 1. Sebaran Persentase Responden. 
usia 30 tahun ke atas sebanyak 25\%. Apabila diamati secara rata-rata persentase, respons masyarakat dalam mengapresiasi produk PkM berupa inovasi penerapan gaya hidup sehat berbasiskan kolaborasi budaya sangat merata, tidak begitu terlihat ketimpangan usia yang dominan. Selisih persentase tersebut dimungkinkan karena akses informasi produk PkM ini dominan diperoleh dari media YouTube, sedangkan YouTube secara penggunaan dan daya aksesibilitasnya mayoritas kategori remaja dan dewasa, yaitu rentang usia $17-30$ tahun.

\section{Probabilitas dan Efektivitas Produk PkM}

Berdasarkan probabilitas atau kemungkinan tindakan lanjutan bagi produk $\mathrm{PkM}$ dan efektivitas produk, diperoleh hasil sebaran persentase mereka yang setuju dan tidak setuju. Khusus ukuran setuju dibagi menjadi dua opsi, yaitu setuju dan sangat setuju. Mereka yang memilih setuju dalam probabilitas produk tertinggi terdapat pada indikator "Inovasi dalam melaksanakan protokol kesehatan dapat berkolaborasi secara baik dengan budaya" dan "Inovasi budaya dalam mematuhi protokol kesehatan perlu dilakukan", inovasi budaya sangat didukung dan diterima oleh masyarakat sasaran. Sementara itu, dalam ukuran efektivitas produk diperoleh angka tertinggi dalam hal "Produk inovasi ini perlu untuk diinformasikan kepada orang lain”. Hal ini memberikan informasi bahwa budaya dapat berterima dan menjadi sarana sosialisasi penerapan protokol kesehatan pada era pandemi COVID-19 ini.

Beberapa responden juga menunjukkan ketidaksetujuan dari masing-masing pertanyaan, tetapi jumlah yang ada sangat sedikit dibandingkan dengan mereka yang setuju terhadap probabilitas dan efektivitas produk PkM berupa tembang macapat Pocung Bingkas Corona dan Gambuh Kurasing Hawa. Selanjutnya, ketidaksetujuan responden dirangkum sebagai berikut ini.

- Ketidaksetujuan terhadap pernyataan inovasi dalam melaksanakan protokol kesehatan dapat berkolaborasi secara baik dengan budaya karena budaya yang digunakan dalam kolaborasi sangat bersifat tradisional.

- Ketidaksetujuan terhadap pernyataan inovasi budaya dalam mematuhi protokol kesehatan perlu dilakukan karena tidak semua orang mengerti dan memahami yang dimaksud dengan inovasi budaya.

- Ketidaksetujuan terhadap pernyataan budaya perlu dimasukkan dalam pembuatan produk inovasi terkait dengan pelaksanaan protokol kesehatan karena tidak semua orang mengerti dan memahami yang dimaksud dengan unsur budaya.

- Ketidaksetujuan terhadap pernyataan kedua tembang yang digunakan dapat mempermudah dalam melaksanakan protokol kesehatan karena kurang memahami bahasa Jawa dan bukan orang yang terbiasa berkomunikasi dengan bahasa Jawa, meski begitu tetap dapat menerapkannya karena ada praktiknya.

- Ketidaksetujuan terhadap pernyataan produk inovasi ini menarik untuk diaplikasikan dalam kehidupan sehari-hari karena tidak semua orang dapat memahami dan terbiasa berkomunikasi menggunakan bahasa Jawa sehingga kesulitan dalam melafalkannya.

\section{Indikator Keidealan}

Tanggapan selanjutnya mengenai indikator keidealan sebuah produk yang diukur berdasarkan kepuasan masyarakat diperoleh hasil yang dirangkum dalam diagram batang 
Tabel 5. Efektivitas Produk

\begin{tabular}{|c|c|c|c|c|c|}
\hline No & Pernyataan & TS & S & SS & Total \\
\hline \multicolumn{6}{|c|}{ Sehat dengan Cara Berbudaya } \\
\hline 1 & $\begin{array}{l}\text { Protokol kesehatan penting untuk } \\
\text { dipatuhi saat masa pandemi COVID-19. }\end{array}$ & 0 & 41 & 44 & 85 \\
\hline 2 & $\begin{array}{l}\text { Inovasi dalam melaksanakan protokol } \\
\text { kesehatan dapat berkolaborasi } \\
\text { secara baik dengan budaya. }\end{array}$ & 1 & 43 & 41 & 85 \\
\hline 3 & $\begin{array}{l}\text { Inovasi budaya dalam mematuhi } \\
\text { protokol kesehatan perlu dilakukan. }\end{array}$ & 2 & 46 & 37 & 85 \\
\hline 4 & Inovasi ini perlu dinasionalkan. & 0 & 42 & 43 & 85 \\
\hline 5 & $\begin{array}{l}\text { Budaya perlu dimasukkan dalam } \\
\text { pembuatan produk inovasi terkait } \\
\text { pelaksanaan protokol kesehatan. }\end{array}$ & 1 & 38 & 46 & 85 \\
\hline & Rata-Rata dalam Persentase & $0,94 \%$ & $49,41 \%$ & $49,65 \%$ & 425 \\
\hline \multicolumn{6}{|c|}{ Efektivitas Produk } \\
\hline 1 & $\begin{array}{l}\text { Kedua tembang yang digunakan } \\
\text { dapat mempermudah dalam } \\
\text { melaksanakan protokol kesehatan. }\end{array}$ & 3 & 38 & 44 & 85 \\
\hline 2 & $\begin{array}{c}\text { Produk inovasi ini menarik untuk } \\
\text { diaplikasikan dalam kehidupan sehari-hari. }\end{array}$ & 2 & 45 & 38 & 85 \\
\hline 3 & $\begin{array}{c}\text { Produk inovasi ini dapat digunakan } \\
\text { sebagai bahan edukasi atau pembelajaran } \\
\text { mengenai gaya hidup sehat. }\end{array}$ & 0 & 41 & 44 & 85 \\
\hline 4 & $\begin{array}{l}\text { Produk inovasi ini perlu untuk } \\
\text { diinformasikan kepada orang lain. }\end{array}$ & 0 & 51 & 34 & 85 \\
\hline & Rata-Rata dalam Persentase & $1,47 \%$ & $51,47 \%$ & $47,06 \%$ & 340 \\
\hline
\end{tabular}

\section{Keterangan:}

TS : Tidak setuju

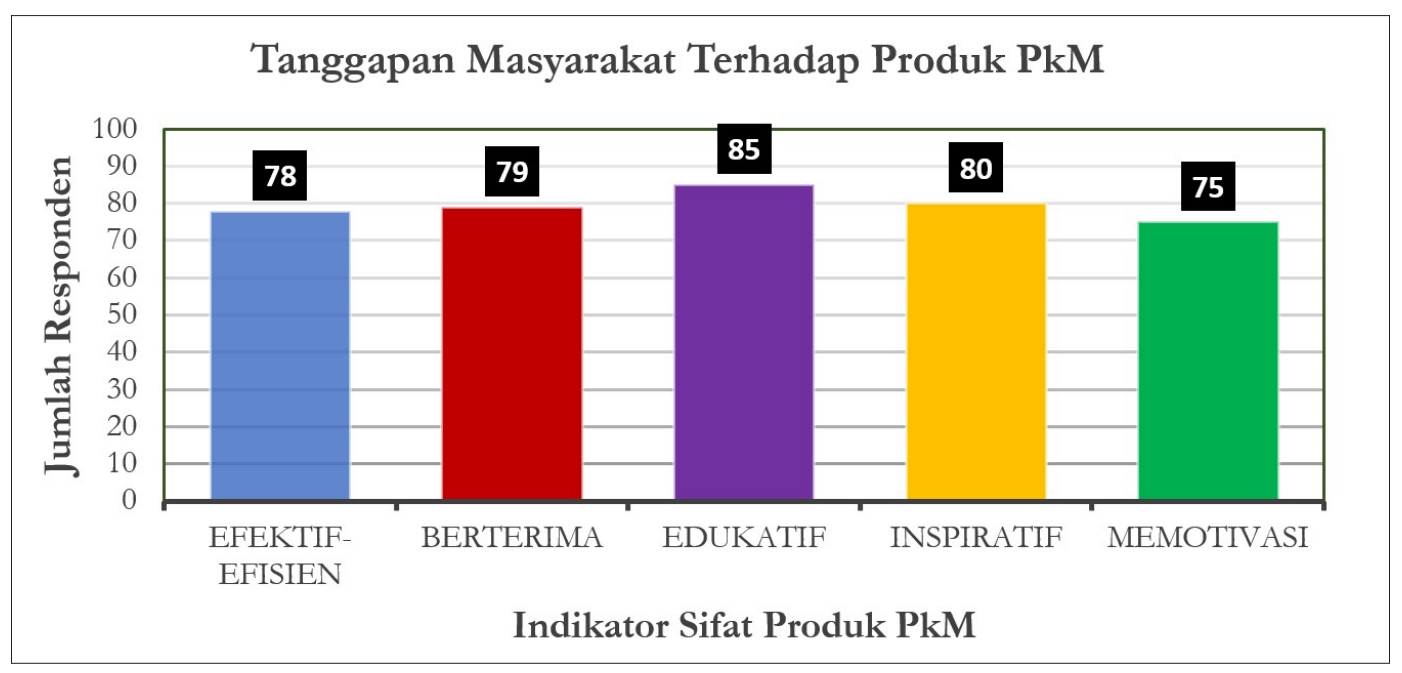

Grafik 1. Tanggapan Atas Indikator Keidealan Produk PkM. 
berikut. Indikator keidealan merupakan aspek ukuran yang diharapkan dalam sebuah produk sehingga memiliki kebermanfaatan (Bahar, 2015:15). Kebermanfaatan yang dirasakan oleh konsumen produk, dalam hal ini masyarakat sasaran, baik masyarakat budaya Manggis maupun sasaran secara luas, adalah merasakan kepuasan atas beberapa indikator yang dipersepsikan melalui perbandingan pikir atau psikologisnya dalam kaitan hasil dan tindakan yang didapatkan (Peterson et al., 1993). Indikator yang muncul adalah keefektif-efisienan, keberterimaan, edukatif, inspiratis, dan memotivasi. Berdasarkan rekap data kuesioner diperoleh tanggapan berdasarkan persepsi masyarakat sasaran bahwa produk sangat edukatif, diikuti inspiratif, berterima, efektif-efisien, dan memotivasi.

\section{Produk Pendukung Berupa Poster dan Leaflet}

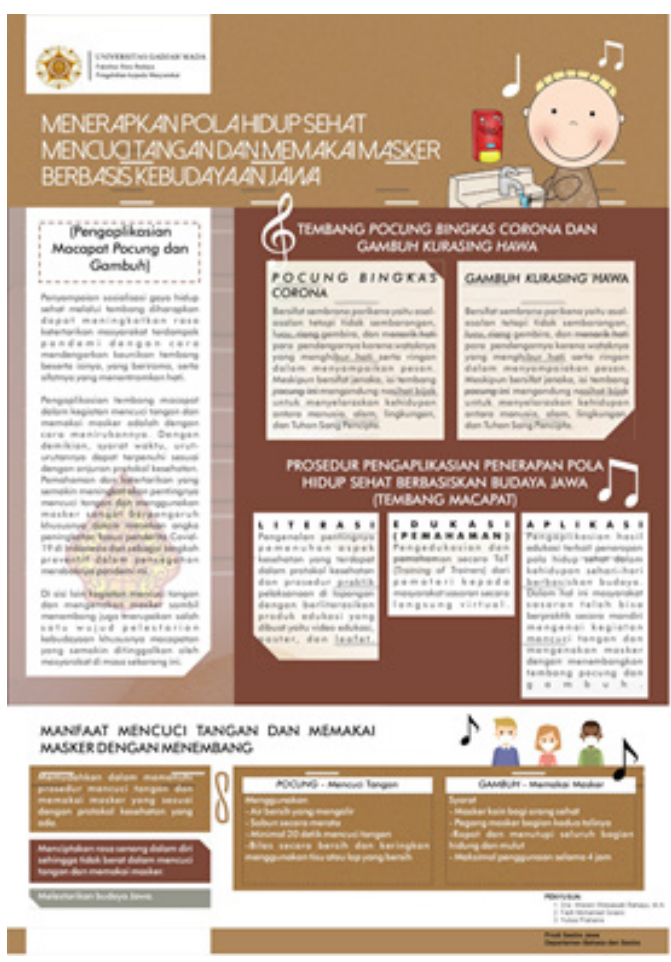

Gambar 3. Poster.
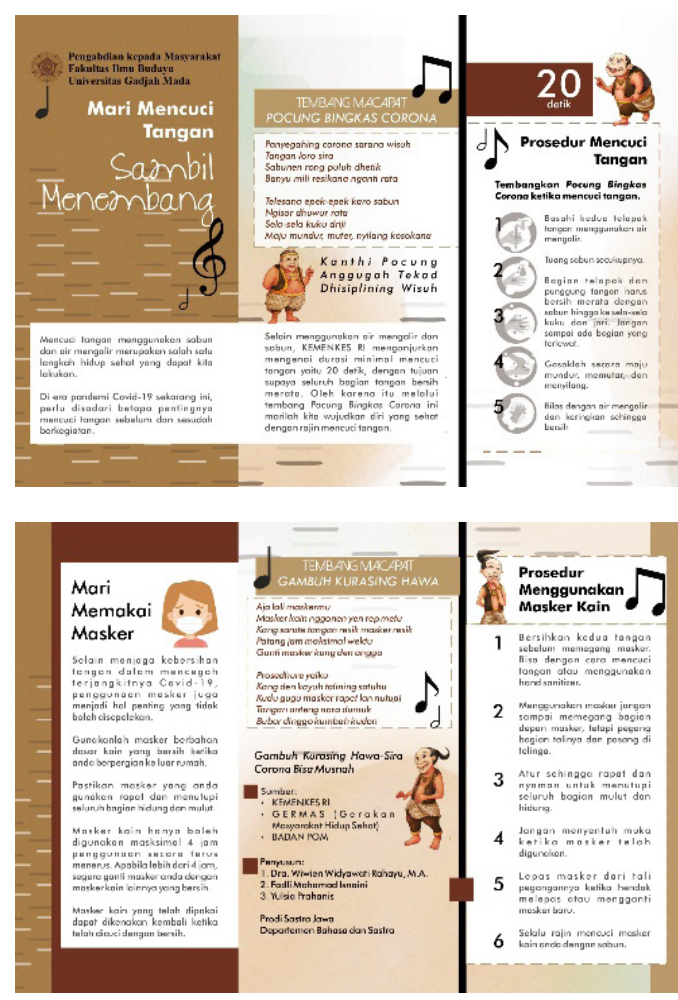

Gambar 4. Leaflet halaman depan dan belakang.

\section{Kritik, Saran, dan Harapan Terkait PkM Beserta Produk}

Tabel 6. Kritik, Saran, dan Harapan Terkait PkM Beserta Produk.

\begin{tabular}{|c|l|l|l|}
\hline No & \multicolumn{1}{|c|}{ Saran Mengenai Produk } & Kritik Mengenai Produk & Harapan Mengenai Produk \\
\hline 1 & $\begin{array}{l}\text { Sebaiknya, produk PkM ini } \\
\text { disebarluaskan melalui akun } \\
\text { media sosial lainnya seperti, } \\
\begin{array}{l}\text { Facebook, Twitter, Instagram, } \\
\text { Line, dan WhatsApp agar } \\
\text { masyarakat luas dapat dengan } \\
\text { mudah mengaksesnya. }\end{array}\end{array}$ & $\begin{array}{l}\text { Durasi produk } \\
\text { inovasi berupa video } \\
\text { terlalu lama. }\end{array}$ & $\begin{array}{l}\text { Semoga produk inovasi } \\
\text { tersebut dapat dikenal } \\
\text { oleh masyarakat luas. }\end{array}$ \\
\hline
\end{tabular}




\begin{tabular}{|c|l|l|l|}
\hline 2 & $\begin{array}{l}\text { Video akan lebih baik jika } \\
\text { mengurangi volume dari } \\
\text { backsound yang digunakan } \\
\text { agar penjelasan secara } \\
\text { jelas dapat terdengar. }\end{array}$ & $\begin{array}{l}\text { Backsound video produk } \\
\text { terlalu keras sehingga } \\
\text { suara dari penjelasan } \\
\text { kurang begitu jelas. }\end{array}$ & $\begin{array}{l}\text { Semoga produk PkM } \\
\text { tersebut dapat lebih } \\
\text { dikembangkan kembali } \\
\text { agar lebih baik lagi. }\end{array}$ \\
\hline 3 & $\begin{array}{l}\text { Akan lebih baik, jika video } \\
\text { dibuat dengan pencahayaan } \\
\text { yang lebih terang lagi. }\end{array}$ & & $\begin{array}{l}\text { Semoga melalui PkM } \\
\text { tersebut para generasi } \\
\text { muda terpantik } \\
\text { untuk berkarya dan } \\
\text { menginspirasi. }\end{array}$ \\
\hline 4 & & $\begin{array}{l}\text { Semoga ada inovasi } \\
\text { menarik lainnya yang } \\
\text { diciptakan berkolaborasi } \\
\text { dengan budaya Jawa }\end{array}$ \\
\hline 5 & & $\begin{array}{l}\text { Mudah-mudahan ada } \\
\text { inovasi budaya terkait } \\
\text { Covid-19 yang dapat } \\
\text { menginspirasi. }\end{array}$ \\
\hline
\end{tabular}

\section{Identifikasi Budaya Lokal}

Merujuk pada ketercapaian kolaborasi budaya dengan esensi protokol kesehatan dalam menyumbang tawaran atas permasalahan yang ada di masyarakat sasaran. Dalam hal ini, budaya lokal daerah lainnya sangat berpeluang untuk dijadikan sebuah inovasi dan dikolaborasikan. Macapat sebagai media edukasi hanya berfokus dalam olah seni suara dan korelasinya dalam memengaruhi kognitif pembaca, pendengar, maupun penembangnya. Masih ada cabang budaya lokal daaerah lainnya yang juga berpotensi, antara lain seni permainan tradional yang justru lebih kompleks unsur di dalamnya, terdapat olah seni suara, seni gerak, bahkan seni visual dan sastra.

\section{Penutup}

Pengabdian kepada masyarakat berbasiskan kolaborasi budaya pada era pandemi COVID-19 untuk menumbuhkan antusias masyarakat dalam melaksanakan protokol kesehatan yang ada sesuai anjuran dari Kementerian Kesehatan RI menjadi sebuah tantangan tersendiri. Tantangan tersebut berkaitan dengan latar belakang permasalahan yang terjadi bahwasanya muncul rasa jenuh atas bentuk-bentuk sosialisasi penerapan pola hidup sehat dalam protokol kesehatan khususnya berkaitan dengan mencuci tangan dan mengenakan masker. Masyarakat merasa terkekang karena di berbagai tempat disuarakan dan dipasang imbauan-imbauan tersebut. Seiring berjalannya waktu, sikap peduli terhadap diri sendiri menjadi dikesampingkan dan menganggap remeh COVID-19. Dibutuhkan pemahaman dan pemikiran kritis dalam memberikan solusi atau tawaran guna mengatasi permasalahan tersebut. Alasan tersebut menjadi dasar digubahnya dua buah tembang berjudul Pocung Bingkas Corona dan Gambuh Kurasing Hawa sebagai produk dari $\mathrm{PkM}$ ini yang menawarkan inovasi bentuk sosialisasi baru dan pengedukasian masyarakat terkait pentingnya menerapkan protokol kesehatan. Target masyarakat sasaran dipilih berdasarkan kriteria peluang diaplikasikannya PkM ini, meskipun dalam praktiknya justru target mengalami perluasan dan mendapatkan 
respons yang baik dari konsumen produk PkM “Tembang Pocung dan Gambuh sebagai Media Edukasi Gaya Hidup Sehat pada Masyarakat Berbasis Budaya Jawa”. Pelaksanaan $\mathrm{PkM}$ dilakukan dengan pendampingan tidak langsung. Hasil yang didapat hingga akhir periode pengabdian adalah produk diharapkan terus dapat diterapkan dalam kehidupan sehari-hari hingga menjadi suatu kebiasaan menuju hidup yang sehat.

\section{Daftar Pustaka}

Bahar, A. dan Herman, S. (2015). "Pengaruh Kualitas Produk dan Kualitas Pelayanan Terhadap Kepuasan Konsumen dan Minat Beli Ulang”. Jurnal Organisasi dan Manajemen, Vol. 3, hlm. 14-34.

Chodjim, A. (2013). Mistik dan Makrifat Sunan Kalijaga. Jakarta: PT Serambi Ilmu Semesta (Anggota IKAPI).

Darusuprapta. (1989). Macapat dan Santiswara. (Online). Tersedia dalam https://journal. ugm.ac.id/jurnal-humaniora/article/view/2221/1991. Diakses pada 23 Oktober 2020.

Direktorat Jenderal Pencegahan dan Pengendalian Penyakit. (2020). Pedoman Pencegahan dan Pengendalian (P2P) Coronavirus Disease (COVID-19). Dokumen Resmi KEMENKES RI dan P2P per 27 Maret 2020.

Gericke, J.F.S dan T. Roorda. (1901). Javaansh-Nederlandsch Handwoordenboek. Amsterdam: Johanes Muller-E.d. Brill.

Johns Hopkins Coronavirus Resource Center. (2020). Johns Hopkins University Medicine Tersedia dalam https://coronavirus.jhu.edu/map.html, diakses pada 26 Oktober 2020.

KEMENKES RI. (2020). Serba COVID: Cegah COVID-19 Sehat Untuk Semua. Kementerian Kesehatan Republik Indonesia dan Badan POM.

Koentjaraningrat. (1984). Kebudayaan Jawa. Jakarta: Balai Pustaka.

Mahapatra, S. (2015). "Cognitive Training and Reading Remediation”. Journal of Education and Practice, 6(19), hlm. 57-63.

Nugrahani, F. (2012). Reaktualisasi Tembang Dolanan Jawa dalam Rangka Pembentukan Karakter Bangsa (Kajian Semiotik). Program Pascasarjana Universitas Veteran Bangun Nusantara Sukoharjo.

Organization, World Health. (2020). "Pertanyaan dan Jawaban Terkait Corona Virus". Dalam https://www.who.int/indonesia/news/novel-coronavirus/qa-for-public. Diakses pada 25 Oktober 2020.

Osada, S.S. (2019). Kajian Etnomatematika Terhadap Musik Liturgi Inkulturatif Jawa dengan Laras Pelog dan Implementasinya dalam Pembelajaran Matematika. Prodi Magister Pendidikan Matematika, FKIP Universitas Sanata Dharma.

Peterson, C., Maier, S.F., dan Seligman, M.E. (1993). "Learned Helplessness: A Theory for the Age of Personal Control". Theory for the Age of Personal.

Poerwadarminta. (1939). Baoesastra Jawa. Batavia: J.B. Wolters, Groningen.

Rossandy, A.N.B. (2016). "Hakikat Hidup Manusia dengan Sesamanya dalam Tembang Macapat". Jurnal EDU-KATA, Vol 3 (2), 189-196.

Salam, A. dan Wiwien. R. (2019). "Manggis Menuju Kampung Jaranan”. Jurnal Bakti Budaya. Vol. 2, No. 1, hlm. 31-44.

Widhiarso, W. (2005). Pengaruh Bahasa terhadap Pikiran: Kajian Hipotesis Benyamin 
Whorf dan Edward Sapir. Bahasa dan Pikiran. Fakultas Psikologi UGM.

Widyaningrum, N. dkk. (2020). "Serba COVID: Cegah COVID-19 Sehat untuk Semua". Jakarta: Badan POM RI.

Wiratama, N. dan Sumarno, Sri H. (2014). "Nilai-Nilai Tembang Macapat dalam Pembentukan Karakter Bangsa”. Artikel Ilmiah Mahasiswa.

Zahra, H. (2018). Macapat Tembang Jawa, Indah, dan Kaya Makna. Jakarta: Badan Pengembangan dan Pembinaan Bahasa.

*Produk YouTube dapat diakses melalui link berikut: https://youtu.be/4tP1yc6JsXU 